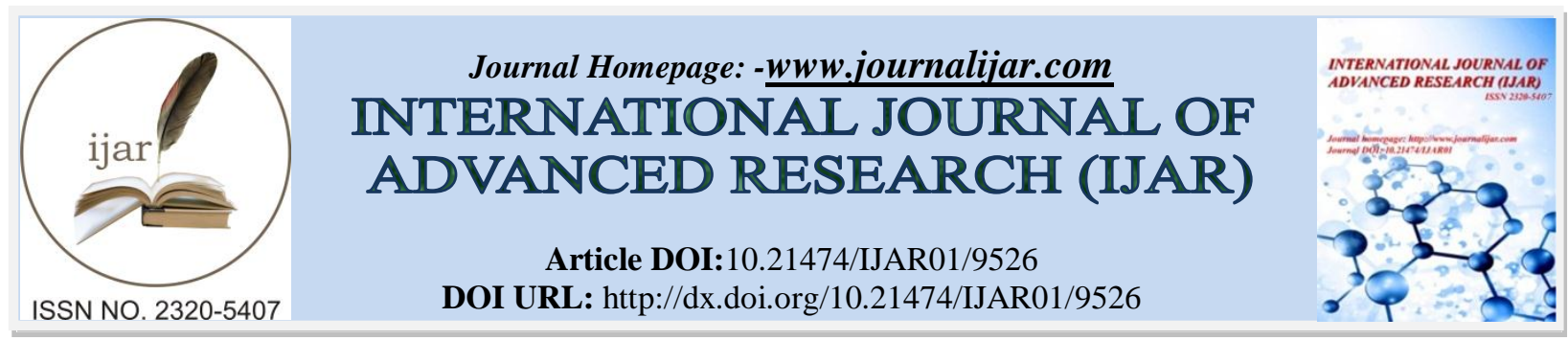

RESEARCH ARTICLE

\title{
PEETHA BHRINGARAJA [WEDELIA CHINENSIS (OSBECK) MERRILL] - AYURVEDIC LITERARY REVIEW.
}

Krishna priya.A ${ }^{1}$ and Dr.Shincymol.V.V ${ }^{2}$.

1. PG scholar, Department of Dravyagunavijnanam, GAVC, Tripunithura.

2. Associate professor, Department of Dravyagunavijnanam, GAVC, Tripunithura.

\section{Manuscript Info}

Manuscript History

Received: 06 June 2019

Final Accepted: 08 July 2019

Published: August 2019

Key words:-

Peetha Bhringaraja, Kesaraja, Wedelia chinensis (Osbeck)Merrill.

\begin{abstract}
Bhringaraja (Eclipta prostrate (L.)) Is a plant widely used for liver disorders and Anaemia. The drug is said to have three varieties based on the colour of its flower. The other two varieties are Peetha Bhringaraja with yellow coloured flower and Nila Bhringaraja with blue coloured flower. The variety Peetha Bhringaraja, Yellow flowered variety is botanically identified as Wedelia chinensis (Osbeck) Merrill. The drug was widely mentioned as an ingredient in many herbomineral preparations in the text books of Rasasasthra. The drug was referred in many literary works as 'Kesaraja'. The drug was popularly used as a remedy for cancer among folk lore practises. The present review article aims at exploring the literature for collecting the available informations regarding the drug Peetha Bhringaraja Wedelia chinensis (Osbeck) Merrill.
\end{abstract}

Copy Right, IJAR, 2019,. All rights reserved.

\section{Introduction:-}

Utilisation of natural resources for human well being dated back to Vedic period. Ayurvedic health care system uses plants and plant based products for treating various ailments. There is an abundant source of knowledge in the ayurvedic literatures regarding the immense therapeutic potentials of many plants, which still remains in the dark without being explored. Nighantus are such literary works which gives a wide range of explanation regarding the properties and therapeutic indications of herbal, mineral and animal source of drugs. Many plants are being explained with its varieties, that may be due to their morphological resemblance or due to similarity in therapeutic utility. But, while considering the practise, most of such varieties remain ignored or not utilised. They lost their popularity as a valuable medicine among main stream practise. Such unexplored plants are now facing the threat of endangerment due to the lack of awareness regarding its medicinal importance.

Peetha Bhringaraja [Wedelia chinensis (Osbeck) Merrill], is such a drug which has lost its attention in the main stream clinical practise among the ayurvedic community. The drug is mentioned as a variety of Bhringaraja (Eclipta prostrate (L.)) in some Nighantus. The drug is popular among folklore practises for their anti cancer activity.

\section{Nirukthi of Peetha Bhringaraja}

Peetha varnayuktho Bhringaraja bhedaha ${ }^{1}$ (Vachaspathyam) - The drug is the yellow coloured variety of Bhringarāja.

Corresponding Author:-Krishna priya.

Address:-PG scholar, Department of Dravyaguna vijnanam, GAVC, Tripunithura. 


\section{Historical back ground Samhitha period}

In Vangasena Samhitha, Athisara adhikara, the drug 'Kesaraja' is adviced to make Gutika with water and taken orally in the condition of amathisara along with pain and bleeding. The commentator Nirmal saxena interpreted that the term Kesaraja in this context is the drug Bhringaraja itself. ${ }^{2}$

\section{Nighantu period}

Sodhala Nighantu in Lakshmanadi varga mentioned two varieties of Bhringaraja. One is with swetha pushpa (White flower) called 'Jayanthi' and the other is with Peetha pushpa (Yellow flower) called 'Avanthi'. Avanthi is said to be similar to Jayanthi (Bhringaraja) with respect to its leaf shape and number of leaves. ${ }^{3}$

Raja Nighantu, in Sathahwadi varga 3 varieties of Markava or Bhringaraja is described based on the colour of flower. They are Bhringaraja, Peetha Bhringaraja and Nila Bhringaraja. Six synonym of Peetha Bhringaraja also mentioned. by Pandit Narahari in Sathahwadi varga. ${ }^{4}$

Saligrama Nighantu, in Guduchyadi varga mentioned three varieties of Bhringaraja. They are Bhringaraja, Peetha Bhringaraja and Nila Bhringaraja. The Nighantukara mentioned the synonyms of Peetha Bhringaraja as similar to that mentioned in Raja Nighantu. ${ }^{5}$

In other Nighantus, no varieties of Bhringaraja are mentioned. In Dhanwanthari Nighantu, Karaviradi varga the drug Bhringaraja is included and has got Kesaranjana as synonym. In the book, 'Studies on material plants and drugs in Dhanwanthari Nighantu' by Dr. D.K.Kamat, three varieties of Bhringaraja is explained. The yellow variety is termed as 'Haripriya'. He explains that Bhringaraja is used for medicinal purpose, Yellow variety is used in worship of deities and the third variety is not differentiated by practitioners. ${ }^{6}$ In Madanapala Nighantu, no varieties are mentioned for Bhringaraja. ${ }^{7}$ In Kaiyyadeva Nighantu (Oushadhi varga) and Bhavaprakasa Nighantu (Guduchyadi varga) the synonyms and properties of Bhringaraja is mentioned. Kesaraja is mentioned as synonym of Bhringaraja. But varieties of the drug is not mentioned..$^{8,9}$

\section{Horthus malabaricus}

Horthus Malabaricus is a 12 - volume treatise on the plant wealth of Malabarpublished in Latin language during the period 1678-1693 from Amsterdam. This drug is included in the $10^{\text {th }}$ volume of the treatise. The name of the drug mentioned is 'Pee-Cajenneam' and 'Peekayyunniyam'. 'Pee' refers to wild and 'Kayyunniyam' refers to Eclipta alba. It is also called as 'Manjakaiyyunniyam'. It occurs in marshy places in coastal lowlands of Malabar, commonly around Cochin. The therapeutic uses of the drug is mentioned as similar to that of Kaiyyunniyam. ${ }^{10}$

\section{Text books of Rasasasthra}

Rasasasthra is the specialised branch of Ayurveda dealing mainly with metals and minerals. The detoxification of metals and minerals was done with various herbs through different type of processing methods. The drug Peetha Bhringaraja and Bhringaraja is being widely used in the formulations of Rasasasthra. Peetha Bhringaraja is referred by the name Kesaraja in most of the literatures. In most of the formulations, Bhringaraja and Kesaraja are used simultaneously. So from this it can be inferred that Kesaraja in that context refers to Peetha Bhringaraja only. In many formulations the drug is included as one of the ingredient, whereas in some formulations it is used for doing Bhavana, a specialised process of trituration. Most of the yogas in which Kesaraja is an ingredient contain heavy metals like Abhraka (Mica), Loha (Iron) etc. In Rasendra chinthamani, Amla pitha Adhikara a Sodhana procedure for Abhraka is mentioned; in which Kesaraja swarasa is one of the bhavana dravya. ${ }^{11}$ The formulations in which Kesaraja is included is indicated predominantly for diseases like Grahani, Amlapitha, Jwara, Jwarathisara, Kasa, Pandu, Prameha, Rajayakshma, Sotha etc.

The reference regarding the name 'Kesaraja' for the drug Peetha Bhringaraja is not present in any of the Nighantus. Instead Kesaraja is being used as a synonym for Bhringaraja in some Nighantus. In the treatises of Rasasasthra, the drug is widely mentioned by the name Kesaraja. May be due to this fact the drug is included in Ayurvedic Pharmacopoeia of India in the name Kesaraja. The description of the drug along with macroscopic and microscopic features is included in API $6^{\text {th }}$ volume. The botanical source accepted for Kesaraja in API is Wedelia chinensis (Osbeck) Merrill. ${ }^{12}$

Synonyms $3,4,5$,

Synonyms of the drug Peetha Bhringaraja is available in Sodhala Nighantu, Raja Nighantu and Saligrama Nighantu. 


\section{Synonyms of Peetha Bhringaraja}

\begin{tabular}{|l|l|l|l|l|}
\hline Synonyms & Interpretation & So.N & R.N & Sa.N \\
\hline Avanthi & Name of a sacred city & + & & \\
\hline Deva priya & Dear to the Gods & + & + & + \\
\hline Dvijathaka & Twice born & + & & \\
\hline Haripriya & Liked by Vishnu, Possess yellow coloured flower & + & + & + \\
\hline Harivasa & Wearing yellow garland, Possess yellow flower Purifier & + & + & + \\
\hline Pavana & That which is able to purify & & + & + \\
\hline Pitha bhringa & Yellow coloured variety of Bhringaraja & + & & \\
\hline Pithru priya & Dear to ancestors & + & & \\
\hline Swarna bhringara & That possess yellow coloured flower & & + & + \\
\hline Vandaniya & Which is to be respectfully greeted, or that possess yellow flower & + & + & + \\
\hline
\end{tabular}

\section{Rasapanchaka}

The ayurvedic pharmacological properties are Rasa, Guna, Virya, and Vipaka. There is no direct reference regarding the Rasapanchaka of Peetha Bhringaraja in Nighantus. The literary reference of Rasapanchaka of Peetha Bhringaraja is available from Ayurvediya Oushadha Nighantu of Thayyil Kumaran Krishnan ${ }^{13}$ and from API. ${ }^{12}$

Rasapanchaka of Peetha Bhringaraja

\begin{tabular}{|l|l|l|}
\hline & Ayurvediya Oushadha Nighantu & API \\
\hline Rasa & Thiktha & Katu, Thiktha, Kashaya \\
\hline Guna & Ruksha, Laghu, Theekshna & Theekshna \\
\hline Virya & Ushna & Ushna \\
\hline Vipaka & Katu & Katu \\
\hline
\end{tabular}

Action of Peetha Bhringaraja on doshas ${ }^{12}$

Vatha hara, Kaphahara

Other Karmas of Peetha Bhringaraja ${ }^{12}$

Muthrala, Hridya, Vrishya, Swedakara, Kesya, Balya

Therapeutic indications ${ }^{12}$

Arsa, Athisara, Dourbalya, Hridroga, Indralupta. Jwara. Krimi, Kamala, Kasa, Pandu, Pliha vridhi, Sirasula, Slipada, Sthriroga, Sula, Swasa, Vrana

Prayojya anga (Officinal part) ${ }^{13,12,14}$

In Ayurvediya Oushadha Nighantu of Thayyil Kumaran Krishnan and Vaidyarathnam Oushadha Nighantu written by Kanippayyur Sankaran Namboothirippad, the officinal part mentioned for drug Peetha Bhringaraja is whole plant. In API, the drug Kesaraja consists of dried whole plant of Wedelia chinensis (Osbeck) Merrill excluding the root.

\section{Aamayika prayoga}

1. In Amathisara with Sula and bleeding, Kesaraja is made into pills along with water and taken orally. ${ }^{2}$

2. Kesaraja prayoga in Jwara is mentioned in Bhaishajya rathnavali. The root of the drug Kesaraja is taken and made into seven pieces and each piece is taken daily along with Ardraka, cures all types of Jwara. ${ }^{15}$

3. A special prayoga is mentioned in Bhaishajya rathnavali, Bala roga chikitsa for curing condition called Anamaka, and protect child from Bhutha etc. A cloth which is soaked in Kesaraja swarasa. The fruit hair of Arka and hair of sheep is kept inside the cloth. Then the cloth is made into a varthi, which is then dipped in thaila, made to burn and Kajjali prepared out of it. This is then applied as anjana on a child. ${ }^{16}$

4. The juice of Peetha Bhringaraja along with iron rust mixed in cow's urine is taken for dropsy.

5. Decoction of leaves with fresh oil mitigates head ache. ${ }^{10}$ 


\section{Formulations}

References of formulations of Peetha Bhringaraja are mainly available from various text books of Rasasasthra. The drug is being widely used as both ingredient as well as bhavana dravya in many formulations.

Formulations in which Peetha Bhringaraja is an ingredient

\begin{tabular}{|l|l|}
\hline Name of formulation & Reference \\
\hline Grahani mihira thailam & Bhaishajya rathnavali, Grahani chikitsa, 583 \\
\hline Bhaskaramritha abhrakam & Bhaishajya rathnavali, Amlapitha chikitsa, 34 \\
\hline Kshudhavathi Gutika brihathi & Bhaishajya rathnavali, Amlapitha chikitsa, 84 \\
\hline Vyaghri thailam & Bhaishajya rathnavali, Balaroga chikitsa, 151 \\
\hline Sindhooradi thailam & Bhaishajya rathnavali,Galagandaadirogachikitsa - 83 \\
\hline Nayanamritha loham & Bhaishajya rathnavali, Nethra roga cikitsa, 227 \\
\hline Viswa vallabha ghritham & Bhaishajya rathnavali, Pradara roga chikitsa,100 \\
\hline
\end{tabular}

Formulations in which Peetha Bhringaraja is a Bhavana dravya

\begin{tabular}{|c|c|}
\hline Name of formulation & Reference \\
\hline Balaroganthaka rasa & Bhaishajya rathnavali, Balaroga chikitsa, 112 \\
\hline Brihat rasendra gutika & Bhaishajya rathnavali, Kasa chikitsa, 91 \\
\hline Sarivadi vati & Bhaishajya rathnavali, Karna roga chikitsa, 72 \\
\hline Lakshmi vilasa rasa & Bhaishajya rathnavali, Kasa chikitsa, 130 \\
\hline Kasa samhara bhairava rasa & Bhaishajya rathnavali, Kasa chikitsa, 84 \\
\hline Kamalanthaka loham & Bhaishajya rathnavali, Pandu roga chikitsa, 45 \\
\hline Chandra suryathmako rasa & Bhaishajya rathnavali, Pandu roga chikitsa, 74 \\
\hline Sarveswara rasa & Bhaishajya rathnavali, Prameha chikitsa, 180 \\
\hline Kanchanabhra rasa (Brhat) & Bhaishajya rathnavali, Rajayakshma chikitsa, 143 \\
\hline Rasabhra manduram & Bhaishajya rathnavali, Sotha chikitsa, 124 \\
\hline Sothankusho rasa & Bhaishajya rathnavali, Sotha chikitsa, 53 \\
\hline $\begin{array}{l}\text { Sudha Nidhi (As Bhavana drava and } \\
\text { Anupana) }\end{array}$ & Bhaishajya rathnavali, Sotha chikitsa, 104 \\
\hline Sri vaidyanatha vatika & Bhaishajya rathnavali, Grahani roga chikitsa, 301 \\
\hline Achinthya sakthi rasa & Bhaishajya rathnavali, Jwara chikitsa, 575 \\
\hline Vishama jwaranthaka loham Brhat & Bhaishajya rathnavali, Jwara chikitsa, 1155 \\
\hline Rasabhra vati & Bhaishajya rathnavali, Grahani chikitsa, 315 \\
\hline Khasarpana vatika & Bhaishajya rathnavali, Grahani chikitsa, 308 \\
\hline Rasendra gutika & Rasendra chinthamani, Kasa chikitsa 1 \\
\hline Brihat paneeya baktha gutika & Rasendra chinthamani, Amlapithadikara, 45 \\
\hline Thriphaladi mandura & Rasakamadhenu, Amlapitha chikitsa \\
\hline Abhra vatika & Rasendra sara Sangraha, Jwarathisara chikitsa, 13 \\
\hline Jathiphaladi gutika & Rasendra sara Sangraha, Grahani chikitsa, 11 \\
\hline Baidyanatha vati & Rasendra sara Sangraha, Grahani chikitsa, 48 \\
\hline Rasabhra vati & Rasendra sara Sangraha, Grahani chikitsa, 120 \\
\hline Brihat kanchanabhra rasa & Rasendra sara Sangraha, Yakshma chikitsa, 65 \\
\hline Brihat rasendra gutika & Rasendra sara Sangraha, Kasa chikitsa, 1 \\
\hline Kasa samhara bhairava rasa & Rasendra sara Sangraha, Kasa chikitsa, 11 \\
\hline Lakshmi vilasa rasa & Rasendra sara Sangraha, Kasa chikitsa, 17 \\
\hline Bala rasa & Rasendra sara Sangraha, Bala roga chikitsa, 1 \\
\hline Bala roganthaka rasa & Rasendra sara Sangraha, Bala roga chikitsa, 6 \\
\hline
\end{tabular}

\section{Conclusion:-}

Apart from Nighantus the drug is mentioned in textbooks of Rasasasthra. None of the Nighantus have mentioned the name Kesaraja for the plant. Instead, the name Kesaraja is the synonym of Bhringaraja in some Nighantus. But most of other books have mentioned Peetha Bhringaraja by the name Kesaraja. API also included the drug by this name and botanically identified as Wedelia chinensis (Osbeck) Merrill. The drug is not popularly used in practise, may be due to the confusion in the name Kesaraja. The drug was said to possess similar therapeutic action as that of 
Bhringaraja. Peetha Bhringaraja is a promising drug of choice as Vishahara, Balya and Rasayana. More clinical researches have to be carried out with this drug and should promote the conservation and cultivation of the drug.

\section{Acknowledgement:-}

I am greatly thankfull to Dr.P.Y.Ansary, Professor and H.O.D, Department of Dravyagunavijnana, GAVC, Tripunithura for his constant guidance and motivation. I am thankfull to Dr.Shincymol.V.V, Associate professor, Department of Dravyagunavijnanam, GAVC, Tripunithura, my guide, for her immense support and guidance throughout the work. I express my deep gratitude to Dr.Sara Moncy Oommen, professor, Department of Dravyagunavijnanam, GAVC, Trivandrum for her moral support and adivices.

\section{References:-}

1. Sri. Tharanatha tharkavachaspathi Bhattacharya, Vachaspathyam, $6^{\text {th }}$ volume, Chaukamba Sanskrit series office, Varanasi, 2006th edition

2. Dr. Nirmal saxena, Vangasena samhitha or Chikitsa sara Sangraha of Vangasena, Chaukambha Sanskrit series office, Varanasi,second edition 2014, Volume 1, p .115

3. Prof.Gyanendr Pandey, Acharya sodhala's Sodhala Nighantu, Chowkambha Krishnadas Academy, Varanasi, First edition, 2009, Lakshmanadi varga, p .13

4. Narahari. Rajanighantu of pandit Narahari, Dr.Indradeva Tripathy, Chaukambha Krishnadas Academy, Varanasi, p.89

5. Saligrama, Saligrama Nighantu bhushanam, or Bhrihat Nighantu rathnakara, 7-8 bhaga, Khemaraj Srikrishnadas Prakasan, Bombay, P. 325

6. Dr.S.D.Kamat, Studies on medicinal plants and drugs in Dhanwanthari nighantu, Chaukambha Sanskrit Pratishtan, Delhi, P. 280

7. Dr.Gyanendra Pandey, Sri Madanapala rachita Madana vinoda, Madanapala Nighantu, Chaukambha orientalia, Varanasi, 2012, P. 158

8. Sharma PV and Sharma Guru Prasad, Kaiyadeva Nighantu, Reprint edition, Ch. 1,Ver:68-70 Varanasi, Choukhambha orientalia,2013, P. 637

9. Prof.K.C.Chunekar, Dr.G.S.Pandey, Bhavaprakasa Nighantu Of Sri.Bhavamisra, Chaukambha Bharathi academy, Varanasi, 2013, P. 414

10. K. S. Manilal , H. Y. Mohan Ram. On the English edition of Van Rheede's Hortus Malabaricus. University of Kerala, Thiruvananthapuram, 2003, Volume 10, 42, P. 152

11. Prof.Sidhi nandan mishra, Rasendra chinthamani by Acharya Dundukanath, Chaukambha orientalia, Varanasi, P. 270

12. Ayurveda Pharmacopoeia of India, $1^{\text {st }}$ edition, Government Of India, Ministry of Health and Family welfare, Part 1,Vol 6

13. Thayyil kumaran Krishnan, Dr.M.P.Sreedharan nair, Ayurvediya Oushadha Nighantu, Publication department, Ayurveda college, Thiruvananthapuram,1979, P. 59

14. Kanippayyur Sankaran Nambuthirippad, Vaidyarathnam Oushadha Nighantu, Panchangm Pusthakasala, Kunnamkulam, P. 500

15. Bhishagrathna shri Brahmasankar Misra, Govinda Das, Bhaishajya rathnavali, Chaukambha prakasan, Varanasi, Jwarachikitsa, P. 112

16. Bhishagrathna shri Brahmasankar Misra, Govinda Das, Bhaishajya rathnavali, Chaukambha prakasan, Varanasi,Bala roga chikitsa, P. 1075. 